\title{
TECHNICAL CO-OPERATION IN SOUTH AND SOUTH-EAST ASIA
}

$\mathrm{T}$ HE report for 1961-62 of the Council for Technical Co-operation in South and South-East Asia emphasizes that, in moving into its second decade, the Colombo Plan has become truly international, its 22 members including ten non-Commonwealth countries, and, outside the region, Australia, Britain, Canada, Japan, New Zealand and the United States. More than 24,000 persons from the countries of the area have received train. ing in other Colombo Plan countries, and more than 4,000 experts have visited the area. Scientific, technical and training equipment to the value of more than $£ 32$ million has been supplied to the area and the total value of technical assistance supplied under the Plan now exceeds 1102 million. The proportion of expenditure allocated to experts, trainees and equipment has remained fairly stable during the past few years, but the distinction between the giving and receiving countries has become gradually blurred. An astonishing and inestimable reservoir of goodwill has been created among its makers and constituted one of the most successful postwar ventures in international trust and co-operation.

The United Kingdom provided 656 new training places during the year, bringing the total provided under the Plan to 4,536 , compared with 9,335 by the United States, 4,071 by Australia, 1,863 by Canada, and 1,914 by India. The United Kingdom provided 47 new experts during the year, making a total of 493 under the Plan, compared with 1,833 provided by the United States, 488 by Australia, 425 by Japan, 293 by Canada, 446 by India, and 180 by New Zealand. The United Kingdom provided $£ 362,571$ worth of equipment during the year, making a total of $£ 2,372,359$ out of the $£ 32,643,789$ provided under the Plan. Altogether in 1961-62, the

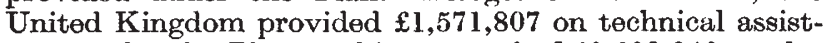
ance under the Plan, making a total of $£ 8,623,240$, exclusive of aid given to North Borneo and Sarawak under the Colonial Development and Welfare Acts. The United Nations and its specialized agencies has also supplied 9,149 experts and 6,951 Fellows to the area during the period of the Plan, and of these experts supplied during the year under the Plan, 103 were in general and 27 in technical education, 72 medical and health, 122 food, agriculture and forestry, 194 engineering, 253 transport and communications, 63 administration, 60 industry and trade and 29 social services.

Apart from continuing as a normal function of the Colombo Plan Bureau the survey of training facilities at the technical level in the area provided by the Mills Report, the Bureau has directed the attention of members of the Council to a recommendation of the Sub-committee on Technical Co-operation for a survey of technical assistance needs in the region and has suggested that each country should survey its needs and send the reports to the Bureau for circulation through the Council. The report also stresses the need for the developing countries to think in terms of long-term economic growth based on a rational use of manpower and material resources rather than short-term expediency and for a continuing critical evaluation of the productivity of technical co-operation. The continuing importance of technical co-oporation as a means of removing the shortage of the trained manpower neoded for an increased tempo of economic development cannot, however, be overemphasized.

of trends during the year the report notes that about 25 per cent of expenditure was on trainees, nearly 40 por

* Department of Technical Co-operation. Technical Co-operation under the Colombo Plan: Report for 1961-62 of the Council for Technical Cooperation in South and Solth-East Asia, Colombo, October 1962. Pp. 92.
(London: H.M.S.O., 1962.) 5 s. net. [See also p. 215 of this issue of Nature. cent on experts and advisers and the remainder on books. films and equipment. There was a marked increase in the number of training places provided by countries within the region and the United States provided almost half the total training awards made during the yoar. Long-term assignments for experts were increasingly popular but expenditure on all forms of technical co-operation is increasing.

The examples of British contributions to technical co-operation which follow will illustrate the range of effort covered. In agriculture the British Government repeated its offer of training in the technology of stored products, entomology and rodent control and a laboratory assistant from Malaya was accepted for a two-year course at the Central Veterinary Laboratory of the Ministry of Agriculture, Fisheries and Food, while equipment is being suppliod for use at the Vetorinary Research Laboratory in Burma. Forest officers from Ceylon, Pakistan and Burma have attended the postgraduate course for forestry officers from tropical countries at the Imperial Forestry Institute, Oxford, and Britain is also supplying equipment to the Pakistan Forest Institute at Peshawar.

The Atomic Energy Commission of Pakistan is to establish an Institute of Nuclear Science and Technology and also proposes to establish training centres at graduate and postgraduate levol in different fields of nuclear energy. To implement this programmo, six trainees are following courses at the University of Manchoster. The Government of India has obtained for five years the services of the Deputy Director-General of the National Coal Board of Britain, who will advise the Indian Coal Development Corporation on tho development of three underground coal mines at Jaraughdi, Katanka and Swant. Britain has also provided Burma with the services for two years of an expert in jute grading and baling to assist in supervision and training of personnel in the jute production drive of the Agriculture and Rural Development Corporation. In addition to providing elevon oxperts and training for eighteen officers for the Operations Division of the Ceylon Transport Board, the British Government has now provided two rolling-stock engineers for one year, several short training courses in bus operation and larger courses for ongineers and depot managers, etc. A deputy superintendent of police from Pakistan received three months training in Britain with county and city police forces and training was arranged with British Railways for a senior mochanical engineer of the Railway Staff Colloge, Baroda, the works manager. Central Workshops, Mysore, a district mochanical enginoer of the South-Eastern Indian Railway and the mechanical engineer (operating) of the Eastern Railway. Training of six-months duration in aircraft maintenanee was arranged for throe trainees from Indonesia's Civil Aviation Acadomy at various institutions in Britain, and Britain is providing an expert, training facilities and equipment for the Telecommunieations Departmont of the Federation of Malaya, while three engineers aro being trained in transistor technology for the Community Listening Contres of the Government of India, and a tochnician of the Burma Broadcasting Service is taking a one-yoar course in electronics at the University of Southampton.

In health services the British Government arranged a two-yoar course in radiation physics to supply the physicist of the radiotherapy unit at tho Cancer Institute. Meheragana, Ceylon, with specialized training and loanod a physiotherapist to the Rangoon Goneral Hospital to re-organize the Physiotherapy Department and train personnel. Training in oral surgery is boing provider 
at the Institute of Dental Surgery, London, and Mount Vernon Hospital, Middlesex, for the supervisor and instructor of Thailand's School of Dentistry, and an assistant surgeon of the Mandalay General Hospital is taking a three-year postgraduate course in dentistry at the Dental School, Guy's Hospital, while at the request of Thailand a one-year course in applied nutrition and food sciences was arranged at the London School of Hygiene. A health educator and public health inspector from Malaya is studying for a diploma in health education at the Institute of Education, London, and Pakistan has been assisted to start the F.R.C.S. (Primary) course of the Royal College of Surgeons, London, while to meet the shortage of qualified anæsthetists in Burma, a civil assistant surgeon is following a two-year course in anæsthesiology at the Postgraduate Medical School, London.

In education, Britain arranged a two-year course in concrete technology for an assistant professor of the College of Technology, Coinbatore; a librarian from Malaya is following a one-and-a-half year course in librarianship at the North-Western Polytechnic, London; five trainees from Malaya, Indonesia and the Philippines attended a course in tropical agriculture offered by the British Government, and an engineer from Nepal a postgraduate course in chemical engineering at Battersea College of Technology. Seven teachers from Indonesia's Science Teaching Centre, Bandung, are attending two- to threeyear courses in teaching science at Sheffield; science laboratory equipment, chemicals and books were supplied to five State high schools in the Shan States of Burma. A postgraduate course for two trainees from the University of Philippines was arranged at the Royal College of Science and Technology, Glasgow, and arrangements made for the senior lecturer of the Physics Department, University of Sind, to undertake nuclear research at Trinity College, Oxford, while a trainee from the Birbal Sahni Institute of Palæobotany is taking a postgraduate course at Queen's University of Belfast. The President of Burma's Shan State Civil Service is being trained in public administration in Britain, while five Laotian trainees attended a six-month course at the Royal Institute of Public Administration.

\section{THE UPPER CRETACEOUS OF CENTRAL EUROPE}

$\mathrm{T}$ HE Palæontological Section of the Geological Society in the German Democratic Republic held a sym. posium in Dresden during October 2-7, 1962, on "Problems of the Stratigraphy and Palæontology of the Cenomanian to Coniacian Stages in Central Europe". Three days of papers with discussion and three days of excursions in Saxony were organized by Dr. H. Prescher of the Staatliches Museum für Mineralogie und Geologie zu Dresden and Dr. K.-A. Tröger of the Geologisches Institut der Bergakademie Freiberg (Sachs). The meetings were attended by some thirty geologists, mostly from the German Democratic Republic, but also from Czechoslovakia, Hungary, Poland and Great Britain. The eighteen papers read will be published early in 1963 in the Berichte der Geologischen Gesellschaft in der D.D.R.

General reviews of the present state of knowledge of the Upper Cretaceous in Bohemia were given by $F$. Macák and V. Müller and in papers sent in by J. Soukup and J. Dvorák. A useful summary has already been published by Soukup in tabular form with German transliterations of all the Czech localities mentioned.

The extensive work by Polish geologists on the flyschfacies of the Carpathians, thrust northwards into southern Poland, has become well known in Britain in recent years, mainly through the work of M. Ksiazkiewicz and his colleagues at Krakow ${ }^{2,3}$. The post-war work on the boreal facies in Poland is, as yet, less well known. A general summary of this recent work was given by $\mathbf{S}$. Cieśliński, who has already published work on the Albian and Cenomanian which has faunal and facies similarities to north-west Europe ${ }^{4,5}$. For the symposium he had prepared a map which showed the Cretaceous basins in Poland and the facies-succession distribution in each basin. The Silesian-north Sudetic Cretaceous, lying to the southwest of the Sudetenrand Fracture, Eule Gneiss and the North Sudetic Schiefergebirge, was discussed in more detail by $J$. Milewicz, and is distinct from the rest of Poland, being allied to the Saxony-Bohemian region.

Six of the papers were largely or entirely concerned with Saxony itself. Much detailed work has been done here since the comprehensive summary by Seifert ${ }^{6}$. The fresh-water beds, widely developed at the base, have already been studied by Prescher ${ }^{7}$ and Barthel ${ }^{8}$. W. Krutzsch (president of the Palæontology Section) gave an account of the micro-flora obtained from a boring at Königstein. Of the marine formations, not only the Unterquader but also the Plenus Zone has commonly been included in the Cenomanian by Saxon geologists; the Czechs have considered the Plenus Zone to be Turonian and this conforms with British usage; some Czech and Saxon geologists now refer to it as a transitional zone between the two stages. In Saxony the Plenus Zone contains Metoicoceras spp., which show that it corresponds to the Actinocamax Plenus Zone in England.

Detailed isopachytes for the Unterquader plus Plenus Zone prepared by F. Decker show that Seifert's palæogeographical maps are misleading and must have depended much on guesswork, at least for land-sea distribution. Decker's map shows a general increase of thickness to the north-east of the Elbtalgebiet beneath the southwesterly overthrust Lausitzer granodiorite. The same granodiorite conceals sediments of the North Sudetic Basin as shown by borings near Spremberg reported on by W. Haller. One of these showed some $1,100 \mathrm{~m}$ of marly clays and fine sandstones embracing only the Turonian to Lower Campanian. The coring was sufficiently wide to allow recovery of a considerable fauna of ammonites and Inoceramus spp.

The considerable thicknesses of detrital shelf sediments in Saxony above the Cenomanian were noticeable in the excursions. In southern Saxony there are more than $500 \mathrm{~m}$ of orthoquartzites (the Quadersandstein) in the Turonian alone. The provenance of this sand is still a problem and H.-D. Beeger has found that the non-opaque heavy minerals are almost confined to the stable trio zircon, tourmaline and rutile. Current bedding is often not developed and does not give a consistent pattern. The contrast with north-west Europe is further shown by the scarcity of glauconite and rarity of phosphate.

The next session of the Geological Society in the German Democratic Republic will be in Leipzig during May 13-18, 1963, on the theme "Facies". Further information can be obtained from J. Lamprecht, Wiss. Sekretär der Geologischen Gesellschaft in der D.D.R., Berlin N4, Invalidenstrasse 44, German Democratic Republic.

J. M. HaNCOCK

${ }^{1}$ Soukup, J., Jb. Staatl. Mus. Mineral. Geol. Dresden, 5, 85 (1960).

${ }^{2}$ Ksiazkiewicz, M., Sond. Geolog. Runds., 45, No. 2, 369 (1956).

${ }^{3}$ Ksiazkiewicz, M., Proc. Geol. Soc. Lond., No. 1587, 70 (1961).

${ }^{4}$ Cieśliński, S., Inst. Geol. Warszawa., 28 (1959).

${ }^{3}$ Cieśliński, S., Inst. Geol. Warszawa., 30 (1960).

- Seifert, A., Freiberg. Forschungs., C 14 (1955).

7 Prescher, H., Freiberg. Forschungs., C 34 (1957).

${ }^{8}$ Barthel, M., Jb. Staatl. Mus. Mineral. Geol. Dresden, 4, 102 (1958). 